\title{
APPLICATION OF MODIFIED ATMOSPHERE PACKAGING (MAP) ON FRESH FISH
}

\section{Aplikasi Pengemasan dengan Atmosfir Termodifikasi (MAP) pada Ikan Segar}

\author{
Putri Wullandari and Diini Fithriani'1) \\ 1) Research Institute for Fisheries Post-harvest Mechanization \\ *Correspondence author: Putri Wullandari, KS. Tubun Petamburan VI Jakarta Pusat 10260, E-mail: utides@gmail.com
}

\begin{abstract}
Packaging has many functions, e.g. as containment, to protect products from physical damage, and from $\mathrm{H}_{2} \mathrm{O}, \mathrm{O}_{2}$, and $\mathrm{CO}_{2}$ exposure, as well as to attract the consumers. Based on the technology, packaging can be divided into 3 types i.e. passive packaging, active packaging, and smart packaging. Modified Atmosphere Packaging (MAP) is the most common active packaging found in the market. MAP has been used to extend the shelf life of several fish such as raw whiting (cod family), mackerel, salmon fillet, cod fillet, fresh bluefin tuna fillet, etc. MAP which was combined with freeze-chilling has been proved to extend the shelf life of raw whiting, mackerel, and salmon fillet. MAP also increased cod fillet's shelf life up to 20 days, whiting fillets packed in $100 \% \mathrm{CO}_{2}$ and stored at $4^{\circ} \mathrm{C}$ temperature up to 15 days. MAP combined with antioxidant on fresh bluefin tuna fillets stored at $3^{\circ} \mathrm{C}$ for 18 days was able to extend products shelf life from 2 days (control) to 18 days, meanwhile $100 \% \mathrm{~N}_{2}$ in packaging has protective effect on haemoglobin and lipid oxidation. Packaging innovations and ingenuity will continuously develop MAP that is oriented for consumer, enhance the product, environmentally responsive, friendly, and cost effective.
\end{abstract}

Keywords: active packaging, modified atmosphere packaging, fresh fish product

\begin{abstract}
ABSTRAK
Pengemasan memiliki banyak fungsi, yaitu sebagai wadah, melindungi produk dari kerusakan fisik, paparan $\mathrm{H}_{2} \mathrm{O}, \mathrm{O}_{2}$, dan $\mathrm{CO}_{2}$, dan untuk menarik konsumen. Berdasarkan teknologi pengemasannya, kemasan dapat dibagi menjadi 3, yaitu kemasan pasif, kemasan aktif, dan kemasan pintar. Salah satu contoh pengemasan aktif yang sudah dikenal di masyarakat adalah Modified Atmosphere Packaging (MAP). MAP telah banyak digunakan untuk memperpanjang umur simpan beberapa jenis ikan segar, seperti whiting (sejenis cod), mackerel, filet salmon, filet cod, filet tuna sirip biru, dan yang lainnya. Penggunaan MAP yang dikombinasikan dengan penyimpanan beku dapat memperpanjang umur simpan whiting, mackerel, dan fillet salmon. Filet ikan cod yang dikemas dengan MAP memiliki umur simpan 20 hari sedangkan umur simpan filet whiting yang dikemas dalam $100 \% \mathrm{CO}_{2}$ dan disimpan pada suhu $4^{\circ} \mathrm{C}$ bisa mencapai 15 hari. MAP yang dikombinasikan dengan antioksidan pada filet tuna sirip biru yang disimpan pada suhu $3^{\circ} \mathrm{C}$ selama 18 hari dapat memperpanjang umur simpan dari 2 hari (kontrol) menjadi 18 hari, dan kandungan $100 \% \mathrm{~N}_{2}$ dalam kemasan memiliki efek protektif terhadap haemoglobin dan oksidasi lemak. Inovasi dan kreativitas dalam pengembangan teknologi pengemasan akan terus menyediakan MAP yang berorientasi pada keinginan konsumen, pengembangan produk, ramah lingkungan, dan hemat biaya.
\end{abstract}

Kata Kunci: pengemasan aktif, pengemasan atmosfir termodifikasi, produk ikan segar

\section{INTRODUCTION}

Food packaging serves to protect the products against deteriorative effects, containing the product, communicating to the consumer as a marketing tool, and provide consumers with ease of use and convenience. Main paradigm that changes in packaging is the change from passive packaging into active packaging (Yam et al., 2005). Moreover search for innovation in food and beverages packaging always continued, due to consumer's needs and demands that is affected with changes in global trend, like the increasing of life expectancy (Lord, 2008).

Active packaging is an innovative concept that described as a packaging form where packaging, 
product, and environment interact to extend product's shelf life, safety and sensory properties. This type of packaging usually becomes very important in fresh food (Labuza \& Breene, 1989 in Hutton, 2003). Active packaging leads to the combination of several additives into packaging system. These additives can be attached into inner packages or combined with the packaging materials, aimed to maintain or increase product quality and shelf life. Active packaging has a role in product preservation besides providing inert barrier from the environment (Hutton, 2003). Active packaging is not a new thing, but its advantages in terms of quality and economic value is the latest development in food packaging industry. One of active packaging type is Modified Atmosphere Packaging (MAP). MAP is the removal and/or replacement of the atmosphere surrounding the product before sealing in vapor-barrier materials (McMillin et al., 1999). MAP can be vacuum packaging (VP), which removes most of the air before the product is enclosed in barrier materials, or forms of gas replacement, where air is removed by vacuum or flushing and replaced with another gas mixture before packaging sealing in barrier materials. The headspace environment and product may change during storage in MAP, but there is no additional manipulation of the internal environment (McMillin et al., 1999)

The example of active packaging on fisheries product is the combination of MAP with antioxidantbased active packaging on fresh bluefin tuna fillets stored at $3^{\circ} \mathrm{C}$ for 18 days. Active packaging films were produced by embedding a-tocopherol into an unstabilized low density polyethylene (LDPE) matrix at three concentrations $(0.1 \%, 0.5 \%, 1 \%)$. The ratio between the volume of gas and weight of food product (V/W ratio) was 2.5:1. The result shows that MAP can extend product shelf life from 2 days (control) to 18 days. $100 \% \mathrm{~N}_{2}$ in packages has protective effect on haemoglobin and lipid oxidation. Active film packaging can reduce lipid oxidation, and combination effect of MAP and antioxidant can be used to extend the shelf life of raw fish (Torrieri et al., 2011).

MAP also used in pre-rigor fillet farmed Atlantic cod (Gadus morhua) stored at $0^{\circ} \mathrm{C}$ and the quality was determined through sensory evaluation of raw odour as well as chemical, physical, and microbiological analysis. Cod was packaged under gas to product ratio of 2:1 and $\mathrm{CO}_{2}, \mathrm{O}_{2}$ and $\mathrm{N}_{2}$ were analysed after 7,10 and 14 days of storage. The result shows that the weighted optimum gas mixture for MA packaging of farmed cod was determined to be $63 \mathrm{ml} /$ $100 \mathrm{ml} \mathrm{O}_{2}$ and $37 \mathrm{ml} / 100 \mathrm{ml} \mathrm{CO}$, aerobic and psychrotrophic plate count decreased, and $\mathrm{H}_{2} \mathrm{~S}$ producing bacteria were not present or not able to grow under the different gas mixtures (Sivertsvik, 2006).
This article will discuss about MAP and its application for fisheries product since MAP is widely known as one of the methods which potential to extend fisheries product shelf life.

\section{FISHERIES PRODUCT CHARACTERISTICS}

Fish quality deteriorates rapidly and the shelf life is reduced if they are not handled and stored properly. It was reported that the rate of spoilage doubles every $5.5^{\circ} \mathrm{C}$ rise in temperature.

Spoilage of fish and shellfish resulted from the changes is caused by 3 major mechanisms, i.e:

1. The breakdown of tissue by the fish's own enzymes (cell autolysis). Cell autolysis is the degradation of nucleotides (ATP-related compounds) which is caused by autolytic enzymes. The autolytic changes are contributing to spoilage mainly by making catabolites available for bacterial growth (Huss, 1995 in Gram \& Huss, 1996).

2. The growth of microorganism. Microorganism that usually grow in aerobically stored fish is Gramnegative psychrotrophic non-fermenting rods. Thus, under aerobic iced storage, the flora is composed almost exclusively of Pseudomonas sp. and S.putrefaciens (Gram \& Huss, 1996).

3. Oxidative reactions. Lipid oxidation produces off flavours that smell strongly during peeling and may be tasted even in the peeled product (Bak et al., 1999). Packaging in modified atmospheres depleted of oxygen may improve colour stability and prevent lipid oxidation in chill-stored shrimps (Sivertsvik, 1995).

MAP can be used to supress the spoilage microorganism and oxidative reactions but doesn't have direct effect to autolysis (Mulan \& McDowell in Coles et al., 2003). MAP must be combined with other preservation technique, like refrigeration, to overcome cell autolysis mechanism. There are several important specific intrinsic factors in fish which greatly influence the spoilage of fish, i.e :

1. The poikilotherm nature of the fish and its aquatic environment. The poikilotherm nature of fish allows bacteria with a broad temperature range to grow. For example, the microflora of temperate water fish is dominated by psychrotrophic Gram-negative, rod-shaped bacteria like Pseudomonas, Moraxella, Acinetobacter, Shewanella, Flavobacterium, Vibrionaceae and Aeromonadaceae, but Grampositive organisms such as Bacillus, Micrococcus, Clostridium, Lactobacillus and Corynebacterium can also be found in varying proportions (Liston, 1980 in Gram \& Huss, 1996). 
2. A high post mortem $\mathrm{pH}$ in the flesh (usually > 6.0). This factor has important consequences for the microbiology of fish amongs other factors because it allows the $\mathrm{pH}$ sensitive spoilage bacteria Shewanella putrefaciens to grow.

3. The presence of large amounts of Non-proteinnitrogen (NPN).

4. The presence of trimethylamine oxide (TMAO) as part of the NPN fraction (Gram \& Huss, 1996)

Generally, the major spoilage bacteria found on processed fish are anaerobs including Pseudomonas, Moraxella, Acinetobacter, Flavobacterium, and Cytophaga species. There are several microorganisms that are of particular importance when dealing with MAP fish products, including C. botulinum (Mulan \& McDowell in Coles et al., 2003).

As mentioned earlier, spoilage on fish mainly caused by microorganisms, so the control of microorganisms growth is one of the success parameter of active packaging technology. Microorganisms can be found at the outer surface (skin and gill) and in colon of live fish (Sivertsvik, 2003).

Meanwhile, the microbes that exists inside the body of fresh shrimp are aerobic spoilage bacteria including Pseudomonas, Achromobacter, Flavobacterium and Micrococcus (Lu, 2009); and the spoilage bacteria that exists in captured shrimp are Shewanella putrefaciens and Pseudomonas spp. (Chinivasagam et al., 1996; Matches, 1982 in Lu, 2009). The action of autolysis by inner proteases together with melanosis results in inferior quality in shrimp at the early period of storage while bacterial spoilage makes the shrimp deteriorate during timeterm storage (Martinez-A' Ivarez et al., 2005 in Lu, 2009). Therefore, we need to add preservative that is combined with MAP.

The concern about the use of MAP on fishery products has to do with the fact that non proteolytic

Table 1. Fisheries product and their suitable packaging form/material

Source: Gopal, 2011. 


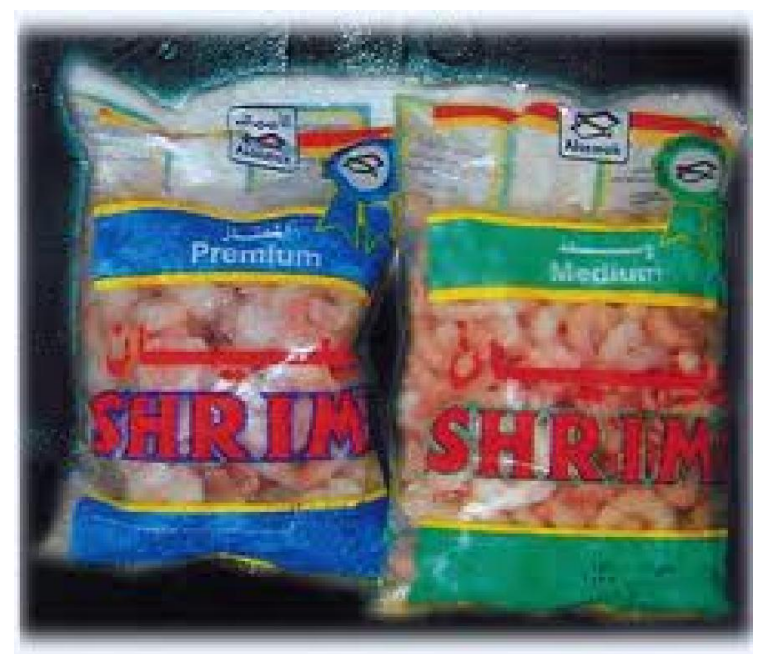

Figure 1. Shrimp in plastic bag and being freezed in Individually Quick Frozen (IQF) (Saudi Fisheries Company, 2005).

botulism strains are found in waters and they can grow at temperatures $<4^{\circ} \mathrm{C}$ (Jay, 2011). Fisheries product and their suitable packaging form / material is shown in Table 1. The example of MAP fisheries product packaging is shown in Figure 1.

\section{MODIFIED ATMOSPHERE PACKAGING (MAP)}

The objective of MAP design is to define conditions that will create the atmosphere best suited for the extended storage of a given product while minimising the time required to achieve this atmosphere condition (Mahajan et al., 2007). The atmosphere gas consists of $78.08 \% \mathrm{~N}_{2}, 20.96 \% \mathrm{O}_{2}$, and $0.03 \% \mathrm{CO}_{2}$. Many food products are rapidly damaged when stored in open air, this is due to reaction with oxygen and the growth of aerobic microorganism like bacteria (Mulan \& McDowell in Coles et al., 2003).

Storage under MAP will extend the shelf life and delaying the rate of spoilage. The success of MAP in extending seafood shelf life depends on many factors, including good initial product quality, good hygiene during slaughter, correct packing material selection, packing equipment, appropriate gas mixture and gasto-product volume $(\mathrm{g} / \mathrm{p})$ ratio for the product, and maintenance of the process temperatures (Sivertsvik, 2007 in Fernandez et al., 2009). In addition, the amount of $\mathrm{CO}_{2}$ dissolved into the product and the storage temperature are the most critical factors (Rotabakk et al., 2008 in Fernandez et al., 2009).

\section{Gases Used in MAP}

There are few gases that involved in MAP, which are Nitrogen $\left(\mathrm{N}_{2}\right)$, Oxygen $\left(\mathrm{O}_{2}\right)$, Carbondioxide $\left(\mathrm{CO}_{2}\right)$, Carbon monoxide (CO), and Argon (Ar). Nitrogen and
Argon are gases that used to create anaerobic/ microaerophilic condition (if the oxygen is removed) (Regenstein, 2006 in Otwell et al., 2006). Nitrogen does not support the growth of aerobic microbes but doesn't prevent the growth of anaerobic microbes. Besides that, $\mathrm{N}_{2}$ is used to maintain the balance of gas pressure in the packaging (Mulan and McDowell in Coles et al., 2003). Bono and Badalucco (2012) reported that striped red mullet treated with ozonated water $\left(0.3 \mathrm{mg} \mathrm{L}^{-1}\right)$ and packaged under MAP $\left(50 \% \mathrm{~N}_{2}\right.$ and $50 \% \mathrm{O}_{2}$ ) can significantly delayed the bacterial growth and the growth levels remained relatively low until day $10\left(<6 \log\right.$ CFU g $\left.{ }^{-1}\right)$.

Oxygen promotes several types of deteriorative reactions in foods including fat oxidation, browning reactions, and pigment oxidation. Therefore, to increase the shelf life of foods, the package atmosphere should contain a low concentration of $\mathrm{O}_{2}$. In some foods, low concentration of $\mathrm{O}_{2}$ resulting in quality and safety problems, so this must be taken into account when selecting the gaseous composition for packaged food (Mulan \& McDowell in Coles et al., 2003). One way to reduce the $\mathrm{O}_{2}$ composition in packaging is by using $\mathrm{O}_{2}$ absorber. Oxygen absorber will actively reduce the $\mathrm{O}_{2}$ concentration in packaging head space until $0.01 \%$, therefore it can prevent oxidation and microorganisme growth (Hurme et al., 2002).

Carbondioxide has negative effect to some microbes if used in sufficient quantities, and it is soluble in water to form mild acid, like $\mathrm{HCO}_{3}$ or carbonic acid. This means that $\mathrm{CO}_{2}$ can migrate to fish and has positive impact, as antimicrobial agent (Regenstein, 2006 in Otwell et al., 2006). Carbondioxide is mostly present in the greatest 


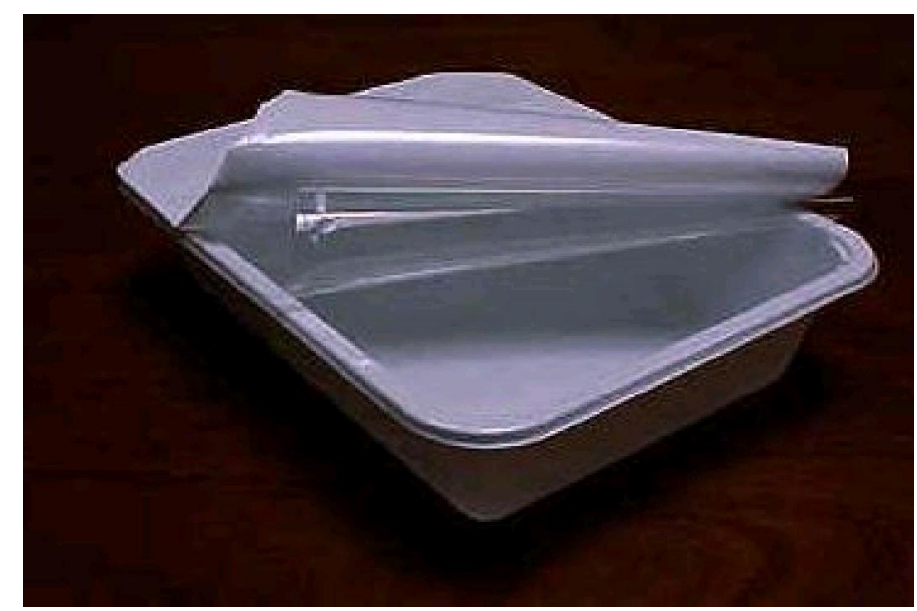

Figure 2. Rigid tray packaging for sandwich (Anon. ${ }^{\mathrm{a}}, 2012$ ).

quantity in MAP. Guldager et al. (1998) reported that Pacific whiting fillet packed in $100 \% \mathrm{CO}_{2}$ and kept at $4^{\circ} \mathrm{C}$ has shelf life up to 15 days. Meanwhile, combination of MAP with super-chiling can extend the shelf life, i.e of Atlantic salmon (Salmo salar) fillets. The samples with the highest $\mathrm{CO}_{2}$ concentration $(90 \%)$ and gas-to-product ratio ( $\mathrm{g} / \mathrm{p}$ ratio) of 2.5 showed the highest shelf life : 22 days vs. 11 days (control sample) based on microbial analysis (Fernandez et al., 2009).

Carbon monoxide has a low solubility in wáter but relatively soluble in some organic solvents. The use of carbon monoxide in MAP (CO-MAP) was approved by the US FDA $(2002,2004)$ for master bags and retail packages. The carbon monoxide is usually used in meat packed with MAP because it binds to the pigment myoglobin, forming carboxymyoglobin. This form of myoglobin exhibits a cherry red color similar to that of oxymyoglobin, the reduced form of myoglobin with bound oxygen (Jeong \& Claus, 2011).

\section{Selection of Packaging Materials for MAP}

Selection of Packaging Materials for MAP is aimed to mantain the quality and safety of packed product. Flexible and semi-rigid laminated plastics are the common materials used for MAP. Laminated plastic is made from polyethylene (PE), polypropylene (PP), polyamide (nilon), polyethylene terephthalate (PET), polyvinyl chloride (PVC), polyvinylidene chloride (PVdC), and ethylene vinyl alcohol (EVOH). Meanwhile rigid and semi rigid plastic is made from PP, PET, unplasticized PVC, and expanded polystyrene. MAP can be achieved by use of polymeric films where gas transmission rate through the film, product respiration, carbon dioxide and oxygen levels within the package are related by a simple material balance (Henig \& Gilbert, 1975 in Christie et al., 1995).
The example of MAP packaging materials used for sándwich, is shown in Figure 2. The cover is made from aluminium foil while the body is made from rigid tray.

Storage temperature is never constant in the distribution chain of fresh produce. Due to the temperature dependence of the respiration rate $(R)$ and of the gas permeability of a packaging film, fluctuating temperatures result in changes of the internal $\mathrm{O}_{2}$ and $\mathrm{CO}_{2}$ concentrations $\left(\mathrm{yO}_{2}\right.$ and $\left.\mathrm{yCO}_{2}\right)$ (Jacxsens et al., 2000).

\section{The Equipment Used for MAP Application}

The Equipment used for MAP Application are :

\section{a. Chamber machine}

Preformed high-barrier bags are manually placed within the chamber before evacuation, back-flushing with the desired gas mixture, and heat sealing (Anon b, 2012). This machine (Fig. 4) is widely used in Indonesia because it is labor intensive, cheap, can be used for big packs but it relatively needs more time to operate.

The product to be packaged is put into a film pouch and placed in the vacuum chamber. When the lid has been closed, the desired level of vacuum is produced in both the vacuum chamber and the pouch. The pouch is then sealed in a vacuum (vacuum package) or the chamber (and thus the pouch as well) is filled with a MAP gas before the sealing operation. The example of chamber machine and digital control panel of chamber machines are shown in Fig. 5.

\section{b. Snorkel machine}

Snorkel machine operates without chamber and using pouch. Bag-in-box bulk products and retail packs inside big packs can be produced using this machine (Mulan \& McDowell in Coles et al., 2003) 


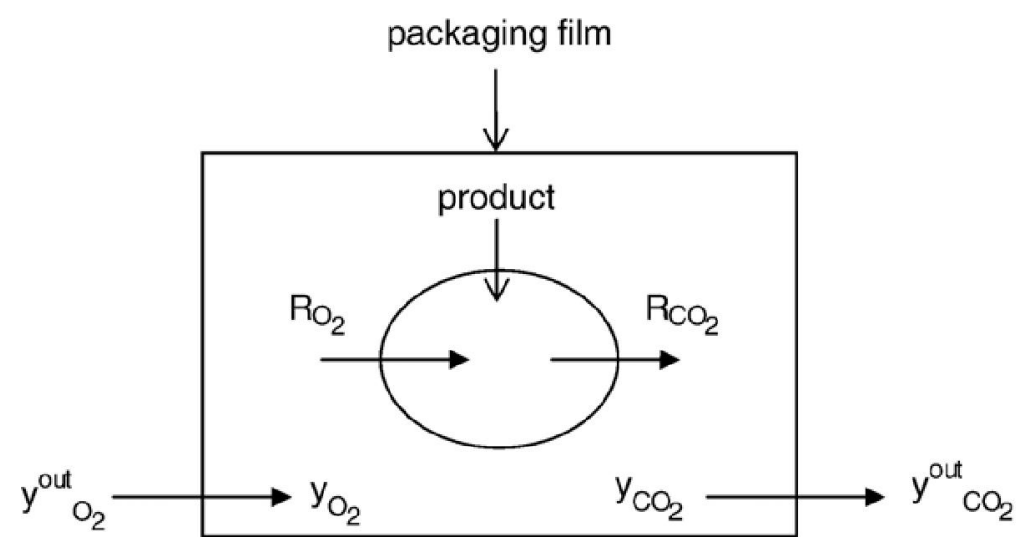

Figure 3. Gas exchange in a modified atmosphere package containing fresh product (Mahajan et al., 2007).

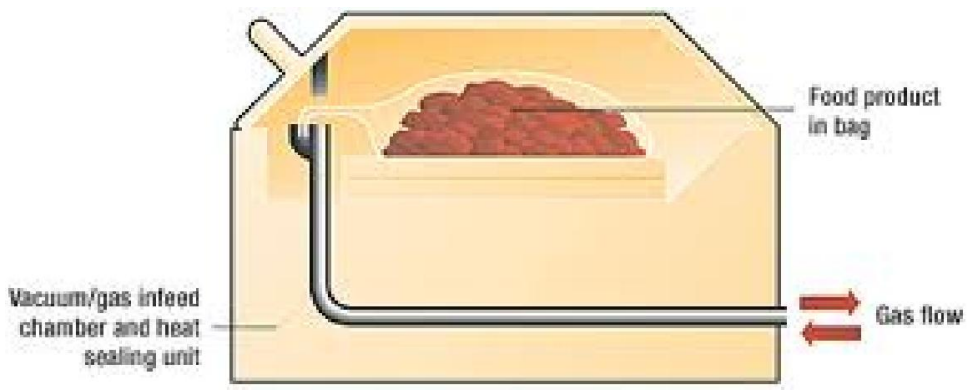

Figure 4. Chamber Machines (Anon., 2012c)

In this machines, preformed plastic bags are positioned on a heat seal mandrel, then the air is removed using retractable snorkels forming a vacuum condition. The vacuum plastic bags are then backflushed with a desired gas mixture and sealed. Snorkel machines is shown in Fig. 6.

c. Form-fill-seal tray machines

Form fill seal (FFS) machine forms pouch from continued roll stock layer. FFS machine consists of 3 types, which are Horizontal Form Fill Seal (HFFS), Vertical Form Fill Seal (VFFS), and Thermoform Form Fill Seal (TFFS).

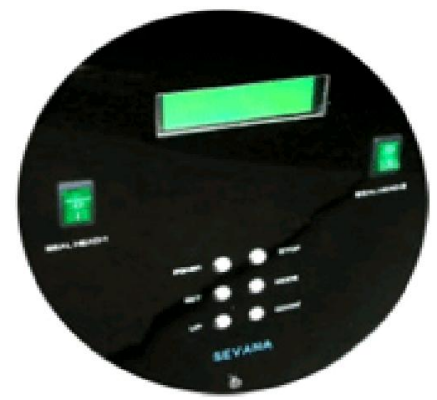

(a)
HFFS machines can overwrap a pre-filled tray of product. The air from the package is removed by a pulse of gas or continuous gas flushing, however gas mixtures containing levels $>21 \% \mathrm{O}_{2}$ cannot be used due to the use of hot sealing jaws at the end of the machine.

VFFS machine forms a tube, it is then filled with product (in most cases dropped from an overhead multi-weigher), purged with gas and then sealed. At the same time film is transported vertically downwards.

Meanwhile in the TFFS machine, packaging material is heated in the forming die and formed into pockets/trays. The formed pockets are then loaded

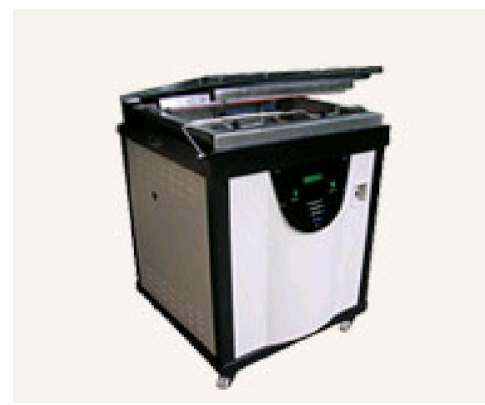

(b)

Figure 5. (a) Digital control panel of chamber machines, (b) Chamber machines (Anon., 2012b). 


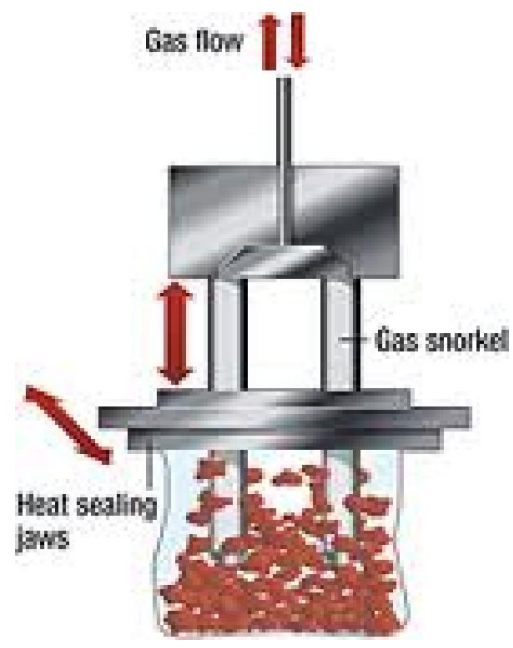

Figure 6. Snorkel Machines (Anon., 2012c).

manually or automatically. The top web of packaging material (lid film) covers the filled pockets/trays. The air is evacuated from the sealing die and protective gas is added. Then the pack is sealed by the application of heat and pressure. Thermoform Form Fill Seal (TFFS) is shown in Fig. 7.

\section{d. Sealing}

Film factor (thickness and treatment to its surface) and plastic composition (resin type, molecular weight distribution, and additional substances) will determine the setting of sealing machine (Mulan \& McDowell in Coles et al., 2003).

FDA compliant hygienic sealing materials range from grades of ethylene propylene rubber (EPDM), acrylonitrile butadiene rubber (NBR), silicone rubber (VMQ), fluoroelastomer (FKM), Hydrogenated Nitrile Rubber (HNBR) and perfluoroelastomer (FFKM) (Warren, 2008). Sealing materials and their suitability to use in different foodstuffs is shown in Table 2.

These packaging materials also have different endurance to sealing temperature, for example the endurance to sealing temperature of $F F K M$ is $310^{\circ} \mathrm{C}$ and VQM is $60^{\circ} \mathrm{C}$ (Warren, 2008).

\section{e. Cutting}

The last packaging stage is to separate the whole packages into individual packages. This can be done using three ways, which are die cutting, longitudinal and transverse cutting (Mulan \& McDowell in Coles et al., 2003).

\section{MAP APPLICATION IN FRESH FISH}

Packaging process for fish, especially fresh fish, highly depends on the temperature. The common packaging temperature is about $0^{\circ} \mathrm{C}\left(32^{\circ} \mathrm{F}\right)$ or lower. The lower the temperature, the slower is the deterioration reaction.

MAP application for fisheries product preservation has been widely known. It can be used alone or combined with other preservation technique like freeze-chilling which is able to extend the shelf life of pacific whiting, mackerel and salmon fillet (Fagan et

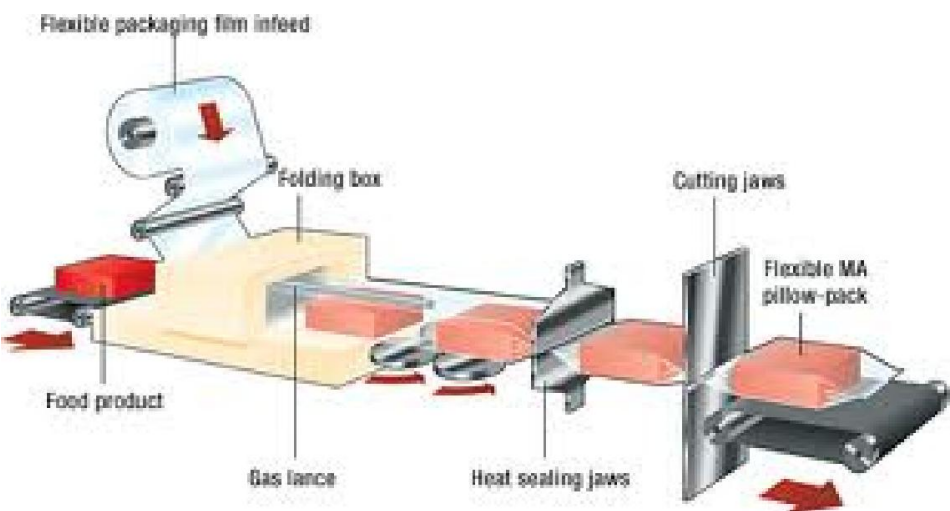

Figure 7. Thermoform Form Fill Seal (TFFS) (Anon., 2012c). 
Table 2. Sealing materials and their suitability to use in different foodstuffs

Note: Generally suitable, ${ }^{*}$ Could be suitable, dependent on grade (Source:Warren, 2008).

al., 2004). Another example of MAP application in fisheries product has been reported Pacific whiting fillet packed in $100 \% \mathrm{CO}_{2}$ and kept at $4^{\circ} \mathrm{C}$ has shelf life up to 15 days (Guldager et al., 1998).

The combination of MAP with refrigeration also shows positive effect to cod fillet quality, especially to fresh-raw cod. Short term frozen storage of cod for 6 weeks at $-20^{\circ} \mathrm{C}$ or $-30^{\circ} \mathrm{C}$ substantially reduced the number of $P$. phosphoreum. This specific spoilage organism was not detected during chill storage of cod fillets previously frozen and stored at $-20^{\circ} \mathrm{C}$ (Boknaes et al., 2000 in Torrieri et al., 2011).

The combination of MAP with super-chiling can extend the shelf life of Atlantic salmon (Salmo salar) fillets. The samples with the highest $\mathrm{CO}_{2}$ concentration $(90 \%)$ and gas-to-product ratio ( $\mathrm{g} / \mathrm{p}$ ratio) of 2.5 showed the highest shelf life which is 22 days while control sample remains only 11 days based on microbial analysis (Fernandez et al., 2009). Superchilling is another technique used to inhibit most autolytic and microbial reactions (Huss, 1995). Several types of cooling systems $\left(-4^{\circ} \mathrm{C}\right.$ to $\left.0^{\circ} \mathrm{C}\right)$ have been used for superchilling of seafood products including the use of flake ice or slurry ice (Losada et al., 2006; Zeng et al., $2005)$ and subzero temperatures during storage $\left(-2^{\circ} \mathrm{C}\right)$ (Sivertsvik et al., 2003).

\section{Quality Analysis of MAP Product}

Some physical and chemical tests have been performed to analyze MAP product, such as color, trimethylamine, water content, total viable count, peroxide value, odor, etc. Torrieri et al. (2011) measured $\mathrm{pH}$ using $\mathrm{pH}$ meter, color with colorimeter, and Thiobarbituric Acid Reactive Substances (TBARS) using extraction procedure from Lemon (1975) and Kilic \& Richards (2003).

Torrieri et al. (2011) reported that the $\mathrm{pH}$ of fresh bluefin tuna fillets was constant throughout storage with no differences among samples. The TBARS values of samples packed with $100 \% \mathrm{~N}_{2}$ were lower than those of control samples, thus $100 \% \mathrm{~N}_{2}$ was chosen as the optimal atmosphere to pack the product. Samples packed in MAP $100 \% \mathrm{~N}_{2}$ showed no change in colour during storage $(p>0.05)$, thus indicating a protective effect of this atmosphere on colour change; so $100 \% \mathrm{~N}_{2}$ atmosphere was the optimal atmosphere in which to pack the product. Moreover, the final report showed that the combined use of MAP and active film resulted in a less oxidized product after 18 days of storage at $3^{\circ} \mathrm{C}$.

Meanwhile, some physical tests have to be performed to ensure the quality of MAP packaging, such as:

1. Heat integrity of packaging seal. Heat integrity of packaging seal is measured using destructive (based on immersing packs in water and checking for escaping gas bubbles around the seal) and non destructive test (based on measuring changes in pressure generated by packs under vacuum in sealed chambers) (Mulan \& McDowell in Coles et al., 2003). 
2. Transmission rate and permeability of packaging film. Transmission rate and permeability of packaging film is measured using isostatic method (both sides of the test film are maintained by passing test gas continuously on one side of the film while inert carrier gas continuously removes permeant from the other side of the film) (Mulan \& McDowell in Coles et al., 2003).

3. Composition of pack headspace. The analysis for composition of pack headspace is performed using $\mathrm{O}_{2}$ and $\mathrm{CO}_{2}$ headspace analyzer for MAP (Fig. 8).

\section{APPLICATION OF MAP IN INDONESIA}

Indonesia has a high temperature and humidity, therefore MAP application can be very interesting and become a compromising opportunity for food industries to develop MAP using local components and based on environmental characteristic or consumen demand.

MAP in Indonesia is mainly used for fresh fruits, because fresh fruits are highly perishable. Fresh fruits still undergo respiration process after being harvested. This respiration produced simple molecules that reduce fresh fruits' quality. Temperature is one of the important factor to determine respiration rate. The higher the temperature, the faster is the respiration rate. Therefore MAP is needed to modify the atmosphere inside the fresh fruits' packages in order to maintain fresh fruits' quality (Hadisumarto, 1997).

An example of MAP in fruit has been done by Hidayat (2005), MAP combined with low temperature storage was used to maintain the quality of rambutan (Nephelium lappaceum, Linn). The results shows that minimally-processed rambutan packed with stretch films (initial concentration: $2-4 \mathrm{O}_{2}, 14-17 \% \mathrm{CO}_{2}$ ) and stored at $10^{\circ} \mathrm{C}$ has shelf life up to 8 days.

However the application of MAP to fresh fish products in Indonesia is rarely used, but it has potency to be developed in the future because it has many advantages especially to extend shelf life of fresh fish products.

\section{The Future of MAP}

Trends in the evolution of food packaging has been changing since decades, started from convenience and marketing orientation in the 1960s; weight, sustainable resources, and energy savings in the 1970s; safety and quality in the 1980s; environmental impact in the 1990s; and safety and security in the 2000s (Han, 2005 in McMilin, 2008). The key to successful packaging is selection of materials and designs, which meet the needs of product characteristics, marketing considerations including distribution and consumer needs, environmental and waste management issues, and cost (Marsh \& Bugusu, 2007).

Consumers demands for more environmentally friendly packaging and more natural products will also create increased demand for packaging from biodegradable and renewable resources (Cutter, 2006). Organic-based materials may be anaerobically degraded while biodegradable polymers from replenishable agricultural feedstocks, animal sources, marine food processing industry wastes, or microbial sources are being developed (Marsh \& Bugusu, 2007).

Nowadays, the equipment widely used in Indonesia is chamber-type machines, because it has the same principle as vacuum packaging machine. The difference is that chamber-type machines can fill or replace the gas inside the pack. In the future it is expected that another MAP machines (chamber machines, snorkel machines, form-fill-seal tray machines, sealing, and cutting machines) and other packaging material (such as polymer films) can be used in Indonesia .

\section{CONCLUSION}

Modified Atmosphere Packaging (MAP) is an active packaging technology that can be used to extend fresh fish's shelf life. MAP can be used alone or combined with other preservation technique, like freeze chilling, refrigeration, and also combined with antioxidant, bactericides, and ozone. In MAP application, gas composition or gas mixture should be well defined, since every gases have different characteristics.

The packaging materials used for MAP in Indonesia usually are flexible and semi-rigid laminated plastic. There are several MAP machines usually used in food industries, but in Indonesia chamber-type machines are usually used. In the future it is expected that other MAP machines (chamber machines, snorkel machines, form-fill-seal tray machines, sealing, and cutting machines) and other packaging material (such as polymer films) can be used in Indonesia.

\section{REFERENCES}

Anonim. 2011. Pengemasan. Retrieved from http:// id.wikipedia.org/wiki/Pengemasan. Accessed on 15 Maret 2012.

Anonymous. 2012a. Packaging Related Machine. Retrieved from http://www.diytrade.com/ china/pd/ 7180952/Modified_Automosphere_Packaging_ Machine.html. Accessed on 24 Maret 2012. 
Anonymous. 2012b. Modified atmosphere Packaging Machines. Retrieved from http://sevana.co.in/ modi_atmospherel.html. Accessed on 17 Februari 2012.

Anonymous. 2012c. Guide to MAP. Retrieved from http:// www. airproducts. ae/food /MAP /guide-to-MAP/MAPmachines.asp. Accessed on 24 Maret 2012.

Bak, L.S., Andersen, A.B., Andersen, E.M., and G. Bertelsen. 1999. Effect of modified atmosphere packaging on oxidative changes in frozen stored cold water shrimp (Pandalus borealis). Food Chemistry. 64: 169-175.

Bono, G. and Cinzia Badalucco. 2012. Combining ozone and modified atmosphere packaging (MAP) to maximize shelf life and quality of striped red mullet (Mullus surmuletus). LWT-Food Science and Technology. 47: 500-504.

Chinivasagam, H. N., Bremner, A. H., Thrower, S. J., and Nottingham, S. M. 1996. Spoilage pattern of five species of Australian prawns: deterioration is influenced by environment of capture and mode of storage. J. of Aquatic Food Product Technology. 5: 25-50.

Christie, G.B.Y., Macdiarmid, J.I., Schliephake, K., and Tomkins, R.B. 1995. Determination of film requirements and respiratory behaviour of fresh produce in modified atmosphere packaging. Postharvest Biology and Technology. 6: 41-54.

Coles, Richard, McDowell, Derek, and Kirwan, M.J. 2003. Food Packaging Technology. Blackwell Publishing Ltd, Australia.

Cutter, C.N. 2006. Opportunities for bio-based packaging technologies to improve the quality and safety of fresh and further processed muscle foods. Meat Science. 74: 131-142.

Fagan, J.D., Gormleya, T.R., and Mhuircheartaigh, M.M.U'ý. 2004. Effect of modified atmosphere packaging with freeze-chilling on some quality parameters of raw whiting, mackerel and salmon portions. Innovative Food Science and Emerging Technologies. 5: 205-214.

Fernández, K., Aspe, E., and Roeckel, M. 2009. Shelf life extension on fillets of Atlantic Salmon (Salmo salar) using natural additives, superchilling and modified atmosphere packaging. Food Control. 20: 10361042

Gopal, and Srinivasa, T.K. 2011. Packaging of Fish and Fishery Products. Downloaded from http:// www. worldfoodscience.org/cms/? pid $=1005100$. Accessed on 16 juni 2011.

Gram, Lone, and Hans Henrik Huss, 1996. Microbiological spoilage of fish and fish products. International Journal of Food Microbiology. (33): 121137.

Guldager, H.S., Bøknæs, N., Østerberg, C., Nielsen, J., and Dalgaard, P. 1998. Thawed cod fillets spoil less rapidly than unfrozen fillets when stored under modified atmosphere at $2^{\circ} \mathrm{C}$. J. of Food Protection. 61 (9): 1129-1136.

Hadisumarto dan Triyanto, 1997. Modifikasi Atmosfer dalam Pengemasan untuk Buah Segar. Buletin Penelitian. XIX (2).
Ode, H.L. 2005. Penyimpanan Buah Rambutan (Nephelium lappaceum, Linn.) Terolah Minimal dalam Kemasan Atmosfer Termodifikasi. Thesis. Sekolah Pascasarjana Institut Pertanian Bogor, Bogor

Hurme, E.,T.S-Malm, Ahvenainen, R., and Nielsen, T. 2002. Active and Intelligent Packaging. In: Minimal Processing Technologies in Food Industry.

Huss, H.H. 1995. Quality and quality changes in fresh fish. In Food and Agricultural organization of United Nations, (paper, F.T., Ed.). FAO, Rome.

Hutton, T. 2003. Food packaging: An introduction. Key topics in food science and technology-Number 7 . Chipping Campden, Gloucestershire, UK: Campden and Chorleywood Food Research Association Group, 108 pp.

Jacxsens, L., Devlieghere, F., Rudder, T. D., and Debevere, J. 2000. Designing equilibrium modified atmosphere packages for fresh-cut vegetables subjected to changes in temperature. LebensmittelWissenschaft Und-Technologie, 33, 178"187.

Jay, and James, M. 2011. Food Preservation with Modified Atmospheres. Modern Food Microbiology, sixth edition. APAC Publishers, Singapore.

Jeong, Youn, J., and Claus, J.R. 2011. Color stability of ground beef packaged in a low carbon monoxide atmosphere or vacuum. Meat Science. 87: 1-6.

Killic, M.B. and Richards, M.P. 2003. Lipid oxidation in poultry döner kebab: pro-oxidative anti-oxidative factors. J. of Food Science. 68: 686-689.

Lemon, 1975. An improved TBA Test for Rancidity. New Series Circular No. 51, Halifax Laboratory, Halifax, Nova Scotia, Canada.

Lord, J.B. 2008. The Food Industry In The United States: Developing New Food Products For A Changing Market Place. 2nd ed. Boca Raton,CRS Press. p 123.

Losada, V., Rodriguez, A., Ortiz, J., and Aubourg, S.P. 2006. Quality enhancement of canned sardine (Sardina pilchardus) by a preliminary slurry ice chilling treatment. European Journal of Lipid Science and Technology. 108 (7): 598-605.

Shengmin, Lu. 2009. Effects of bactericides and modified atmosphere packaging on shelf life of Chinese shrimp (Fenneropenaeus chinensis). LWT-Food Science and Technology. 42: 286-291.

Mahajan, P.V., Oliveira, F.A.R., Montanez, J.C., and J. Frias, 2007. Development of user-friendly software for design of modified atmosphere packaging for fresh and fresh-cut produce. Innovative Food Science and Emerging Technologies 8: 84-92.

Marsh, K. and Bugusu, B. 2007. Food packaging - Roles, materials, and environmental issues. Food Science, 72 (3): R39-R55.

Martinez-A' Ivarez, O., Lopez-Caballero, M.E., Montero, P., and Gomez-Guillen, M.C. 2005. A 4hexylresorcinol-based formulation to prevent melanosis and microbial growth in chilled tiger prawns (Marsupenaeus japonicus) from aquaculture. J. of Food Science. 70: M415-M422. 
McMillin, and Kenneth, W. 2008. Where is MAP Going? A review and future potential of modified atmosphere packaging for meat. Meat Science. 80: p. 43-65.

McMillin, K. W., Huang, N.Y., Ho, C.P., and Smith, B.S. 1999. Quality and shelf-life of meat in case-ready modified atmosphere packaging. In Y. L. Xiong, F. Shahidi, and C. T. Ho (Eds.), Quality attributes in muscle foods (pp. 73-93). New York: ACS Symposium Series, Plenum Publishing Corporation.

Otwell, Steven W., Kristinsson, Hordur G., and Murat O. Balaban. 2006. Modified Atmospheric Processing and Packaging of Fish. Blackwell Publishing, USA

Saudi Fisheries Company. 2005. Individually quick frozen (IQF). Retrieved from http://www. saudi-fisheries.com/ EN/Company/Products/iqf.htm. Accessed on 21 March 2012

Sivertsvik, M. (1995). Shell-on shrimps packed in modified atmosphere. Info. Norcon-serv. No. 9. Report (in Norwegian).

Sivertsvik, M., Rosnes, J.T., and Kleiberg, G.H. 2003. Effect of modified atmosphere packaging and superchilled storage on the microbial and sensory quality of Atlantic salmon (Salmo salar) fillets. J. of Food Science. 68 (4): 1467-1472.

Sivertsvik, and Morten. 2006. The optimized modified atmosphere for packaging of pre-rigor filleted farmed cod (Gadus morhua) is $63 \mathrm{ml} / 100 \mathrm{ml}$ oxygen and 37 $\mathrm{ml} / 100 \mathrm{ml}$ carbon dioxide. $L W T$ - Food Science and Technology. 40 (3): 430-480.

Systech Instrumen, Ltd and Illinois Instrument, Inc. 2010. Oxygen and Carbondioxide Headspace Gas Analyzer.
Downloaded from http://www.systechillinois.com/en/ oxygen-and-carbon-dioxide-headspace-gasanalyzer-gaspace-advance-micro_29.html. Accessed July 29, 2012

Torrieri, Elena, Carlino, Pier Antimo, Cavella Silvana, Fogliano, Vincenzo, Attianese, Illaria, Buonocore, Giovanna Giuliana, dan Paolo Masi, 2011. Effect of Modified Atmosphere and Active Packaging on The Shelf Life of Fresh Bluefin Tuna Fillets. J. of Food Engineering. 105 (3): 429-435.

US FDA. 2002. United States Food and Drug Administration. Agency response letter GRAS notice No. GRN 000083. Washington, D.C., USA Downloaded from: http://www.cfsan.fda.gov/ rdb/opag083.html. Accessed July 29, 2012

US FDA. 2004. United States Food and Drug Administration. Agency response letter.GRAS notice No. GRN 000143. Washington, D.C., USA Downloaded from http://www.fda.gov/Food/ Food I ng redie nts $P$ a c kaging/ GenerallyRecognizedasSafeGRAS/GRASListings/ ucm153974.htm. Accessed July 29, 2012.

Warren, Peel. 2008. Sealing for the food and beverage industry. Sealing Technology. 2008 (9): 11-14.

Yam, K. L., Takhistov, P. T., and Miltz, J., 2005. Intelligent packaging: Concepts and applications. Journal of Food Science. 70 (1): 1-10.

Zeng, Q. Z., Thorarinsdottir, K.A., and Olafsdottir, G. 2005. Quality changes of shrimp (Pandalus borealis) stored under different cooling conditions. J. of Food Science. 70 (7): S459-S466. 


\section{INFORMASI PUBLIKASI PERPUSTAKAAN \\ BALAI BESAR PENELITIAN DAN PENGEMBANGAN PENGOLAHAN PRODUK DAN BIOTEKNOLOGI KELAUTAN DAN PERIKANAN}

\section{BUKU BARU}

1. The Microbiology of Safe Food / BL/ Stephen / 2010

2. Sanitation: Cleaning and Disinfection in The Food Industry / Jian / 2010 / JW

3. Seafood Ecolabeling / 2008 / Phillips / Blw

4. Handbook of Seafood Quality, Safety and Health Application / BLW / Kazuo / 2011

5. Fish Processing: Sustainability \& New Opportunities / WP / Hall / 2011

6. In Pack Processes Food: Improving Quality / WP / Phillip / 2008

7. Environmental Effects on Seafood Availability, Safety and Quality / WP / Kozon / 2011

8. Fish Canning Handbook / 2010 / WI / Bratt

9. Environmentally Compatible Food Packaging / WP / Chiellini / New

10. Microbial Safety of Fresh Product / Blw / Xuetong / 2009

11. Nondestructive Evaluation of Food Quality...2009/spr/by:jha

12. Control of Fish Quality 4th ed / FNB / Connell

13. Principles of Food Toxicology / Pussa / CRC / 2008

14. Food Safety For the 21st Century Managing HACCP ... / 2011 / WI / Wallance

15. Introduction to Food Toxicology 2ed / Takayuki / AP

16. Principles of Microbiological of Troubleshooting in The Indus Food Process Environ /10/Spr/Jeffrey

17. Ingredients in Meat Products: Properties, Functionality and Application / Spr / 2009 / Tarte

18. Handbook of Firezen Food Processing and Packaging 2ed / 2012 / Sun / CRC

19. Jurnal Pengelolaan Hasil Perikanan Indonesia Vol.13 no.2 Tahun 2010, Vol.14 no.1 Tahun 2011 (dari Masyarakat Pengolahan Hasil Perikanan Indonesia/MPHPI)

20. BAWAL Vol.3 No.4, 2011 (dari Pusat Penelitian Pengelolaan Perikanan dan Konservasi Sumber Daya Ikan)

21. Jurnal Standarisasi Vol.13 No. 1 dan 2, Tahun 2011 (dari BSN)

22. Mina bahari Edisi Juni, Juli, November 2011 (dari Pusdatin)

23. TROBOS edisi Agustus, Oktober, November, Desember 2011 dan Januari 2012 (dari PT JAPFA Comfeed Indonesia Tbk)

24. Jornal Pustakawan Indonesia Vol.10 no.2, 2010 (Perpustakaan IPB)

25. SINERGI edisi III/2011 (ITJEN KKP)

26. Warta Pasar Ikan edisi Agustus 2011 vol.96 (Ditjen P2HP)

27. BUDIDAYA Tahun ke- 9 edisi 16,17,19 Tahun 2011 (Dirjen Budidaya)

28. Jurnal Penelitian Perikanan Indonesia (Puslit pengembangan konservasi sumberdaya ikan)

29. Buletin Teknik Litkayasa Sumberdaya Penangkapan (Puslit pengembangan konservasi sumberdaya ikan)

30. Indonesian Fisheries Research Journal (Puslit pengembangan konservasi sumberdaya ikan) 